Die

Theorie and Praxis

der

Geb ur t s h û I f e. 



$$
\text { Theorie und Praxis }
$$

\section{Albert Krause,}

ordentlichem Professsor der Medizin an der Universität Dorpat.

Mit Abbildungen in Stahl und Holz.

\section{Zweiter Theil.}

$$
\text { B e r } 1 \text { i n. }
$$

Druck und Verlag von Georg Reimer.

1853. 
